\title{
COMPARISON OF THE ACTUAL COSTS DURING REMOVAL OF CONCRETE LAYER BY HIGH-SPEED WATER JETS
}

\author{
Rudolf Hela ${ }^{1}$, Lenka Bodnárová ${ }^{2}$, Miloslav Novotný ${ }^{3}$, Libor Sitek ${ }^{4}$, \\ Jiří Klich $^{5}$, Ivan Wolf ${ }^{6}$, Josef Foldyna ${ }^{7}$ \\ ${ }^{1,2}$ Institute of Technology of Building Materials and Components, \\ Faculty of Civil Engineering, Brno University of Technology, Veveri 331/95, \\ 60200 Brno, Czech Republic \\ ${ }^{3}$ Institute of Building Structures, Faculty of Civil Engineering, \\ Brno University of Technology, Veveri 331/95, 60200 Brno, Czech Republic \\ 4, 5, Institute of Geonics AS CR, v. v. i., ICT, Studentská 1768, \\ 70800 Ostrava-Poruba, Czech Republic \\ ${ }^{6}$ NET Ltd., Nádražní 309, 78832 Staré Město pod Sněžníkem, Czech Republic \\ E-mails: ${ }^{1}$ hela.r@fce.vutbr.cz (corresponding author); ${ }^{2}$ bodnarova.l@fce.vutbr.cz; \\ 3novotny.m@fce.vutbr.cz; ${ }^{4}$ libor.sitek@ugn.cas.cz; ${ }^{5}$ jiri.klich@ugn.cas.cz; \\ ${ }^{6}$ wolf@net-waterjet.cz; 7josef.foldyna@ugn.cas.cz
}

Received 02 August 2011; accepted 29 November 2011

\begin{abstract}
This paper describes the process of possible evaluation of costs of using high speed water jet technology for concrete removal methods. High speed water jet technology is a progressive technology of removing damaged concrete used in civil engineering since the 80 's of $20^{\text {th }}$ century. It has been changing and developing since that time. But there is little information in literature devoted to the economic evaluation of this technology. Detailed economic analysis is still missing. This paper aims to compare comprehensively in economic terms the costs of removing concrete using the technology of both continuous oscillating and pulsating oscillating water jets. The research was realized in cooperation with research institutions and industrial companies and was supported by state budget of the Czech Republic and from the European Union. The scheme of cooperation of the University, research institutions, industrial companies and government follows the Triple helix model.
\end{abstract}

Keywords: computation model, total technological costs, total fixed costs, total variable costs, Triple helix model, concrete removal, hydrodemolition, high speed water jet technology.

Reference to this paper should be made as follows: Hela, R.; Bodnárová, L.; Novotný, M.; Sitek, L.; Klich, J.; Wolf, I.; Foldyna, J. 2012. Comparison of the actual costs during removal of concrete layer by high-speed water jets, Journal of Business Economics and Management 13(4): 763-775.

JEL Classification: O32, O14. 


\section{Introduction}

Renovation of concrete structures represents a great part of total turnover of construction industry worldwide. Removal of degraded surface and preparation of surface for renovation materials are very important. As cost of energy and the input of materials grow, it is necessary to look at ways of decreasing cost of removal of degraded concrete. Therefore, it is necessary to choose an optimal and cost effective way of removal of disrupted layers of concrete. The first step towards this goal is to specify the cost of possible ways and technologies of concrete removal for purposes of renovation.

Various types of concrete removal methods can be used. As removal of degraded layers of concrete is costly and ecological aspects are becoming more important than ever before, new technologies with low environmental impact are being developed. Driven by cost, need, and limited resources, the technology for concrete removal is rapidly advancing. Partial removal of critical structural components for repair rather than replacement, geographical constrains, access to structures planned for removal, environmental regulations, and worker and structure safety will continue to effect an evolution of developing methods and equipment (ACI 555R-01 2001). ACI 555R-01 Removal and Reuse of Hardened Concrete state these basic methods for removal hardened concrete:

- hand tools;

- hand-operated power tools;

- vehicle-mounted equipment;

- explosive blasting;

- drills and saws;

- nonexplosive demolition agents;

- mechanical splitters;

- heating and thermal tools;

- and hydrodemolition (water-jet blasting).

Total cost of removal of hardened concrete can be sumarized as costs for removal method, partial or complete concrete removal, reuse, transportation and waste disposal, and additional inspection and testing (ACI 555R-01 2001).

This paper describes the process of possible evaluation of costs of hydrodemolition using high speed water jet technology for concrete removal methods.

\section{Background}

\subsection{Research of high speed water jet technology - cooperation of important institutions and practical use supported by the Government}

Authors have been researching, developing and improving high speed water jet technology for destruction and removal materials for purposes of renovation of concrete structures for a long time. Research institutions the Brno University of Technology, Faculty of Civil Engineering and the Institute of Geonics AS CR, v. v. i. closely cooperate on solving tasks in the research of high speed water jets, interaction with concrete and evaluation of effectiveness of this technology. Many companies focusing on the devel- 
opment of high speed water jet technology cooperate in practical tests of disintegration of various types of material as well as concrete (in particular the Company NET Ltd.). The financial support of the Government, grants as well as checking effectiveness of funding and fulfillment of targets are also very important. Problems for research of high speed water jets have been solved with the support of funding granted by Czech Science Foundation, by the Academy of Sciences of the Czech Republic and by Research and Development for Innovations Operational Program financed by Structural Funds of the European Union and from the means of state budget of the Czech Republic. This scheme of cooperation of the University, research institutions, industrial companies and government follows the Triple helix model.

The Triple helix model is the model of collaboration among business, government and academic actors. The key event is the creation of an entrepreneurial university, whether from an existing academic base or a new foundation, which takes initiatives together with government and industry in creating a support structure for firm formation, regional growth and increasing the competitive advantage of economic development (Etzkowitz, Klofsten 2005).

'Triple helix' model indicates a relationship among academic authorities, industry and authorities as a merger of overlapping areas reflecting an impact of each element on other spheres. There are three main the most common configurations of the 'Triple helix' model: in the first model the areas indicating elements of the industry and academic public exist independently, without any interaction, and the dominant role of an intermediary is played by the authorities being the only element ensuring relations between the sectors; the second model shows interactive relations of different elements; the third model indicates close cooperation among separate institutions of science, business and government (Chlivickas et al. 2009).

Mentioned subjects (Faculty of Civil Engineering, Brno University of Technology, Institute of Geonics AS CR, v. v. i., and NET Ltd.) strive to create the third type of Triple helix model for effective cooperation and to reach innovation in the field of water jet. The third model of 'Triple helix' is the most successful model for high technologies development. This type of Triple helix model shows the highest degree of cooperation among authorities, industry and academic public as the configuration of 'Triple helix' model allows solving all problems in implementation of innovations (Chlivickas et al. 2009).

During solving the problems of high speed water jet technology, the research team registered the following national and international patents:

- Foldyna, J. and Švehla, B.: Method of generation of pressure pulsations and apparatus for implementation of this method. Czech patent No. 299412, 2008.

- Foldyna, J. and Švehla, B.: Method of generation of pressure pulsations and apparatus for implementation of this method. US patent No. 07740188, 2010.

- Foldyna, J. and Švehla, B.: Method of generation of pressure pulsations and apparatus for implementation of this method. EU patent EP1863601, 2011.

- Bortolussi, Ciccu, Foldyna, Sitek: Treatment process of materials, in particular stones, using pulsating jet technology and apparatus to obtain that process. PCT Patent Application No. PCT/IT2009/000184. 
Results of the patents are currently used on the basis of licensed cooperation between industrial party and the Institute of Geonics ASCR, v. v. i. in Ostrava.

The research was supported by state budget of the Czech Republic and from the European Union. In particular, the following projects were realized:

- Development of novel technique for quarrying and cutting of ornamental stones (GA CR No. 105/03/0183, evaluated as excellent).

- Novel technique for cleaning and removal of surface layers and repair of concrete structures (ASCR No. 1QS300860501, evaluated as excellent).

- Study of the process of generation and propagation of pressure pulsations in highpressure system (GA CR, No. 101/07/1451).

- Modelling of the disintegration process of degraded layer of construction materials during their preparation for repair action (GA CR No. 103/07/1662).

- Institute of clean technologies for mining and utilization of raw materials for energy use, reg. No. CZ.1.05/2.1.00/03.0082 supported by Research and Development for Innovations Operational Programme financed by Structural Funds of the European Union and from the means of state budget of the Czech Republic.

With respect to the success achieved as evidenced by the patents of the research team and positive evaluation of finished research projects, it can be stated that Triple helix model cooperation is valuable.

\subsection{High-speed water jet technology}

High-speed water jet represents a technology that is able to disintegrate even the hardest materials due to high energy transmitted to extremely small area (see e.g. Summers 1995). If we use water jets, there is no mechanical tool-material interaction in the process of disintegration. The erosion capability of the jets is widely used for many applications in modern industry. Water jet technology achieved significant progress during last decades in applications such as cutting of wide range of materials, surface cleaning, removal of surface layers and repair of concrete structures. Nowadays, a number of commercial high pressure systems are available on the market, some of them generating pressures up to $400 \mathrm{MPa}$, other delivering up to hundreds liters of water per minute. Water jet cutting and/or cleaning equipment except the pump is lightweight and the whole cutting process can be easily automated. The technology is also very advantageous for the removal of damaged concrete layers from buildings and structures (Hela et al. 2010). The jet is able to remove the damaged layer selectively without the introduction of any additional cracks to construction (in contrast to traditional technologies like jackhammering, grit blasting, milling etc.). Moreover, adhesion strength of coatings applied on surfaces prepared by water jets safely comply with values specified in relevant standards concerned with concrete surface treatment prior to repair (Silfwerbrand 1990).

\subsection{Hydrodemoliton (= concrete removal and cleaning)}

The first serious approach to the use of water jets for concrete hydrodemolition was probably that of McCurrich and Browne (1972). The first commercial hydrodemolition unit was finally developed and introduced after 10 years (Momber 2005). Hydrodemolition 
uses high speed water jet technology. High speed water jet technology is a progressive technology of removing damaged concrete used in civil engineering since the 80's of $20^{\text {th }}$ century. It has been changing and developing since that time.

Equipment for high speed water jet technology ranges from hand-held tools to large tractor mounted units and robots.

The effectiveness of a particular system depends on:

- Nozzle type;

- Nozzling pattern and distance to surface;

- Water pressure; and

- Contact time.

The nozzle is moving rapidly and continually over the area of removed concrete, and excess water is allowed to drain away (ACI 555R-01 2001). The high speed water jet technology makes its destructive action by means of three separate mechanisms:

- Direct impact;

- Pressurization of crack; and

- Cavitation (Medeot 1989).

\subsection{Economical aspects of high-speed water jet technology}

There is little information in literature devoted to the economic comparison of the new technologies with traditional ones. Most of the contributions are dealing with cutting technologies, which occupy the largest volume of applications relative to the others. One of them dealing with the economic analysis of lumber processing systems was published by Manetsch and Huber (1993). Krastel and Drechsel (1999) tested the economy of lasers integrated in a cutting machine during material processing. They realized complete processing of a workpiece with different technologies in one setting. Rather successful comparisons of non-conventional techniques for material cutting are subject in the model by Vidová (2007): costs evaluation and costs analysis is based on measurement of economic effectiveness of the performance of different cutting machines.

Regarding the water jet technology, most of authors interested in the comparison of the advantages of water jet technology with other technologies concentrate solely on the observation of a typical parameter of the technology and on the basis of such analysis then predict the economic advantage or inconvenience. Axinte et al. (2009) used abrasive water jet turning to profile and dress grinding wheels. It was found that grinding wheel can be roughed and semi-finished at considerable lower time compared to that required for employment of conventional (e.g. mechanical) dressers. However, the authors do not address the total cost of the manufacturing process associated with water jet technology and mechanical preparation of grinding wheels (Sitek 2009). Sitek et al. (2009) referred to the research on disintegration of surface layers of corroded and non-corroded concrete by high-speed flat water jets. This type of water jet innovates continuous water jet. Results indicate that progressive type of water jet - so called pulsating water jet - achieved higher efficiency in comparison with the corresponding continuous one in every case. Improvement of the technology follows from the fact that impact pressure generated by the impact of bunch of water on a target is considerably 
higher than corresponding stagnation pressure generated by a continuous jet under the same operating conditions. Unfortunately, detailed economic analysis is missing again. Study on money saving using pulsed water jet was published by Yan et al. (2004) in the paper on delaminated concrete removal by forced pulsed water jet. The use of pulsed technique resulted in saving of $\$ 200 / \mathrm{m}^{2}$ compared to the techniques used earlier (chipping and sandblasting).

Thorough economic analysis of the costs of water jet technology was presented for example by Zeng and Kim (1993). They developed a method for cost prediction of abrasive water jet kerf cutting based on the application of the predicted cutting speed. Their analysis was utilised in the study of Singh and Munoz (1993). They point out that unlike other technologies, using of water jet can save anywhere from 10 to $30 \%$ of total operating costs. They highlighted that economic analysis of the water jet cutting process is somewhat difficult due to three factors: a) the same cutting results can be achieved by many different combinations of cutting parameters, b) the process flexibility, its ability to cut different profiles without hardware changes, is hard to evaluate in most cases, c) different customers have different objectives and they may evaluate various attributes differently. Thus a good economic analysis model should account for these three factors.

This paper aims to compare comprehensively in economic terms the costs of removing degraded layers of concrete road panel using the technology of both continuous oscillating and pulsating oscillating water jets. To generate a pulsating jet, much cheaper equipment (up to 2.4 times) can be used compared to the equipment for generation of continuous jet preserving the same disintegration effects. But what are the actual operational costs?

\section{Experimental procedure and arrangement}

Current study is focused on both continuous and pulsating water jet removal of degraded surface layers of standard road reinforced concrete panel stored at normal outdoor exposure (influence of frost and atmosphere vapours, no chemicals) for approximately 18 years. To determine real volume of disintegrated material, the following types of high speed water jet were used: continuous oscillating and pulsating oscillating jets. A layer of concrete from a concrete panel was removed by means of these two technologies.

The concrete panel was made from the concrete class C30/37 XF3 (compressive strength of about $40 \mathrm{MPa}$ ). Dense aggregate with maximum size of grain $16 \mathrm{~mm}$ was used.

Surface layers were removed step by step from top side of the concrete panel by both continuous oscillating and pulsating oscillating jets. Surfaces with approximate dimensions of $470 \mathrm{~mm} \times 130-250 \mathrm{~mm}$ were treated by this method successively. Disintegrated volume was determined as a measure of the performance of the jet. Tests were performed at various water pressures (30-200 MPa) and nozzle diameters (standard commercial nozzles StoneAge OS7 and MVT Type 916 with nozzle orifice diameter of $0.81,0.97,1.07,1.2,1.4,1.5,1.7$, and $1.8 \mathrm{~mm}$ were used). New water nozzles were used during the tests. Various high pressure pumps were used. Because pulsating jet can be generated at roughly 3 times lower water pressure to disintegrate the 
same volume of concrete compared to corresponding continuous jet (Sitek et al. 2009), much cheaper equipment can be used to do the same work using pulsating technique. Moreover, since surfaces prepared with pulsating water jet demonstrate higher roughness and unevenness compared to the ones treated by continuous jet, better adhesion of coatings and/or repair mortars to substrates prepared by pulsating jet is expected (Sitek et al. 2002). During experiments several couples of treated surfaces with approximately the same value of disintegrated volume were compared to one another. Example of appearance of two compared surfaces is shown in Fig. 1.

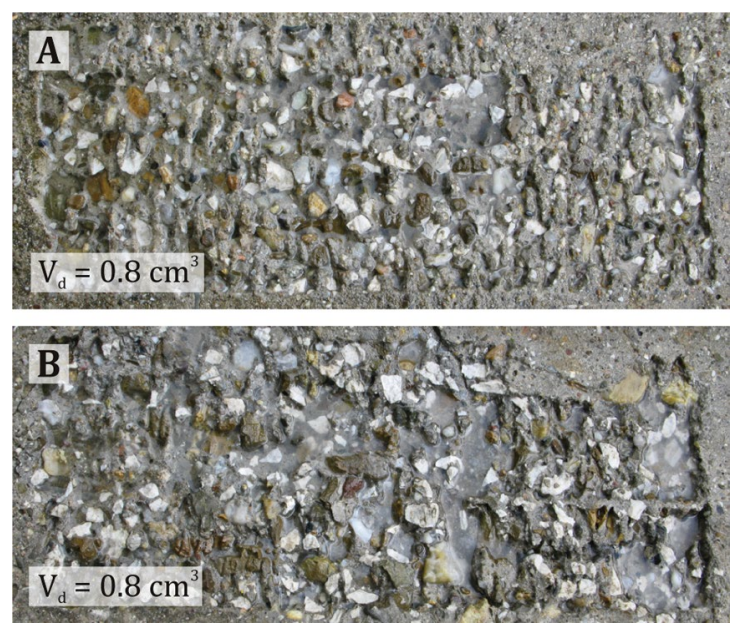

Fig. 1. Comparison of surfaces treated by pulsating oscillating jet (A) with those treated by continuous oscillating jet $(B)$ on concrete road panel $\left(\mathrm{V}_{\mathrm{d}}\right.$ - disintegrated volume, water pressures: $70 \mathrm{MPa}(\mathrm{A}), 200 \mathrm{MPa}(\mathrm{B})$, nozzle diameters: $1.2 \mathrm{~mm}(\mathrm{~A}), 0.81 \mathrm{~mm}(\mathrm{~B})$, stand-off

distances: $50 \mathrm{~mm}(\mathrm{~A}), 45 \mathrm{~mm}(\mathrm{~B})$, material removal rate of area treatment: $12 \mathrm{~cm}^{2} \mathrm{~s}^{-1}$ )

Computational model based on the model presented by Vidová (2007) is completed by specific parameters used during the evaluation of technology of high-speed water jet, as formulated by Zeng and Kim (1993) and Singh and Munoz (1993). The model comes from assumption that total technological costs are the most important technicaleconomic indicator of the operation of machinery and equipment and also a suitable criterion for the comparison of variant solutions.

Total technological costs $C_{\text {total }}$ are specified as the sum of total fixed costs $C_{\text {fixed }}$ and total variable costs $C_{\text {variable }}$. Let's consider the hourly costs for removing the concrete layer. Total costs related to labor hour can be expressed as

$$
C_{\text {total }}=C_{\text {fixed }}+C_{\text {variable }} \text {. }
$$

In fixed costs $C_{\text {fixed }}$, there are included depreciations of production equipment $C_{\text {depr }}$, interests related to security of funds for equipment purchase $C_{i n t}$, rent for production area $C_{\text {rent }}$ and possibly insurance premium for production equipment $C_{\text {prem }}$ :

$$
C_{\text {fixed }}=C_{\text {depr }}+C_{\text {int }}+C_{\text {rent }}+C_{\text {prem }} .
$$


In variable costs $C_{\text {variable }}$ there are included material costs $C_{\text {mat }}$, costs for workers' wages $C_{\text {wage }}$, consumed energy $C_{\text {energy }}$, consumed assistant substance $C_{\text {exc }}$, consumed spare parts and consumables $C_{\text {spare }}$, and costs for maintenance and repairs $C_{\text {main }}$

$$
C_{\text {variable }}=C_{\text {mat }}+C_{\text {wage }}+C_{\text {energy }}+C_{\text {exc }}+C_{\text {spare }}+C_{\text {main }} .
$$

Structure of total costs items for computation model is demonstrated in Fig. 2.

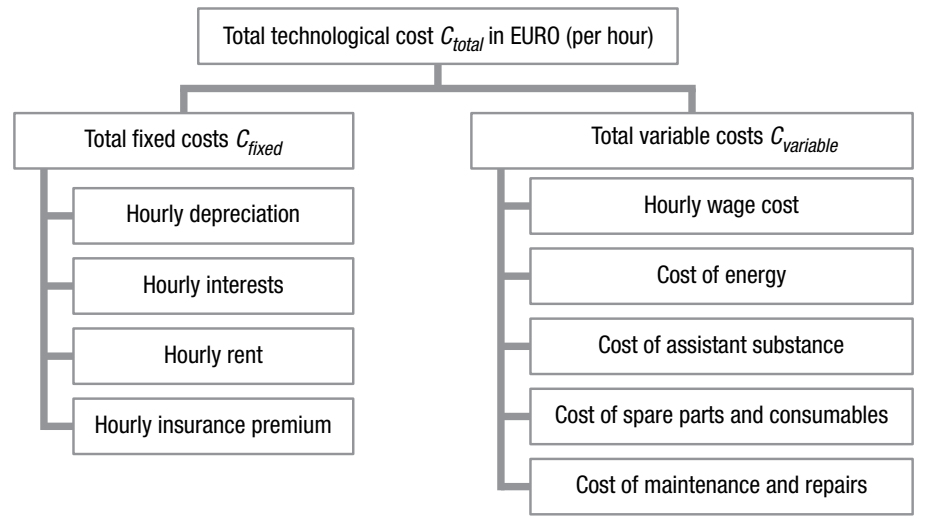

Fig. 2. Structure of total costs items for computation model

Breakdown of items for calculation of total fixed costs and total variable cost for computation model are given in the following Table 1.

Table 1. Example of items in computation model for calculation of fixed and variable costs

\begin{tabular}{|c|c|c|c|c|c|}
\hline & Item & Unit & & Item & Unit \\
\hline 1 & Market entry price of device & EURO & 11 & Wage coefficient & - \\
\hline 2 & Market entry price of pump & EURO & 12 & $\begin{array}{l}\text { Monthly lump price } \\
\text { for energy }\end{array}$ & EURO \\
\hline 3 & $\begin{array}{l}\text { Market entry price of pulsing } \\
\text { device }\end{array}$ & EURO & 13 & Labor hours per month & hour \\
\hline 4 & $\begin{array}{l}\text { Price of handling device } \\
\text { for nozzle movement }\end{array}$ & EURO & 14 & Hourly energy consumption & $\mathrm{kWh}$ \\
\hline 5 & Depreciation period & year & 15 & Price of energy per kWh & EURO \\
\hline 6 & Effective time & hour & 16 & $\begin{array}{l}\text { Price of assistant substance } \\
\text { per liter }\end{array}$ & EURO \\
\hline 7 & Interest rate & $\%$ & 17 & $\begin{array}{l}\text { Hourly consumption } \\
\text { of assistant substance }\end{array}$ & liter \\
\hline 8 & Cost of production area & EURO & 18 & Coefficient of spare parts & $\%$ \\
\hline 9 & Insurance premium & $\%$ & 19 & $\begin{array}{l}\text { Coefficient of maintenance } \\
\text { and repairs }\end{array}$ & $\%$ \\
\hline 10 & Hourly wage & EURO & 20 & $\begin{array}{l}\text { Hourly price for hose } \\
\text { and nozzles }\end{array}$ & EURO \\
\hline
\end{tabular}


Based on equations (1) to (3), the total hourly costs of operation of four different high pressure pumps have been calculated. The following pumps can be used for the removal of desired amount of concrete at desired quality: for low water pressures - Pratissoli HF18 and AQP AQH50, for high water pressures - Uraca KD716 and Uraca KD724. The water jet parameters and results of calculations are given in Table 2. The results of calculations are also shown in Figs. 3 and 4.

Table 2. Comparison of couples of surfaces treated by continuous oscillating jet generated by high pressure and pulsating oscillating jet generated by lower pressure and total hourly costs for removal of specified volume when using specified pump

\begin{tabular}{lccccc}
\hline Jet Type & $\begin{array}{c}\text { Suitable high } \\
\text { pressure pump }\end{array}$ & $\begin{array}{c}\text { Nozzle } \\
\text { Diameter } \\
{[\mathrm{mm}]}\end{array}$ & $\begin{array}{c}\text { Water } \\
\text { Pressure } \\
{[\mathrm{MPa}]}\end{array}$ & $\begin{array}{c}\text { Disintegrated } \\
\text { Volume } \\
{\left[\mathrm{cm}^{3}\right]}\end{array}$ & $\begin{array}{c}\text { Total hourly } \\
\text { costs } \\
{[\text { EUR }]}\end{array}$ \\
\hline Continuous & Uraca KD716 & 0.81 & 180 & 0.8 & 55.86 \\
\hline Pulsating & Pratisolli HF 18 & 1.5 & 50 & 0.8 & 35.39 \\
\hline Continuous & Uraca KD724 & 0.97 & 200 & 1.8 & 79.67 \\
\hline Pulsating & AQP AQH50 & 1.4 & 70 & 1.6 & 44.43 \\
\hline Continuous & Uraca KD724 & 0.81 & 200 & 0.8 & 73.65 \\
\hline Pulsating & AQP AQH50 & 1.2 & 70 & 0.8 & 42.15 \\
\hline
\end{tabular}

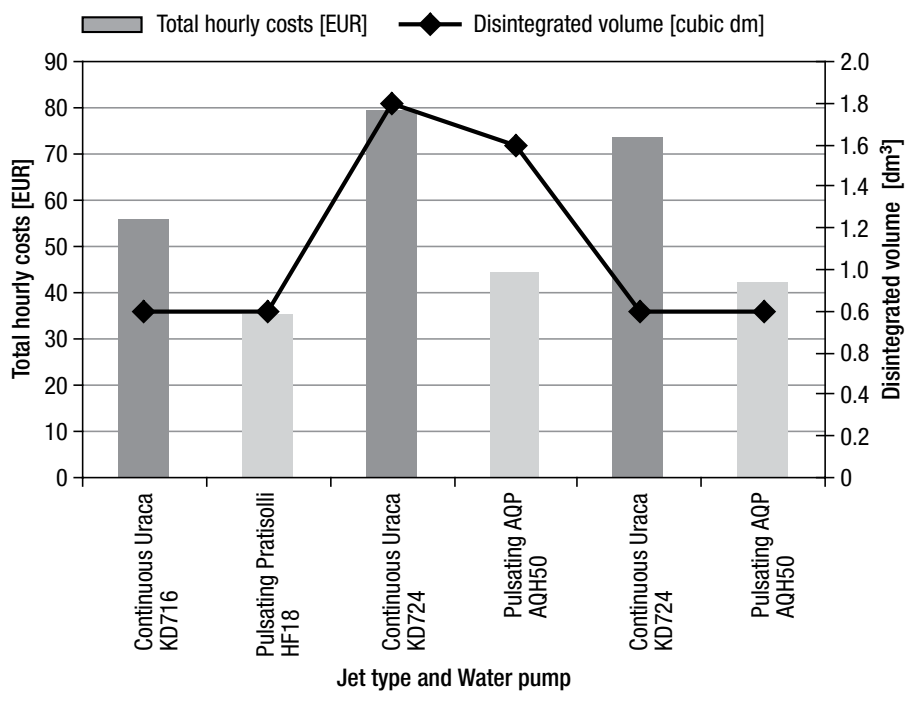

Fig. 3. Total hourly cost for continuous and pulsating water jets 


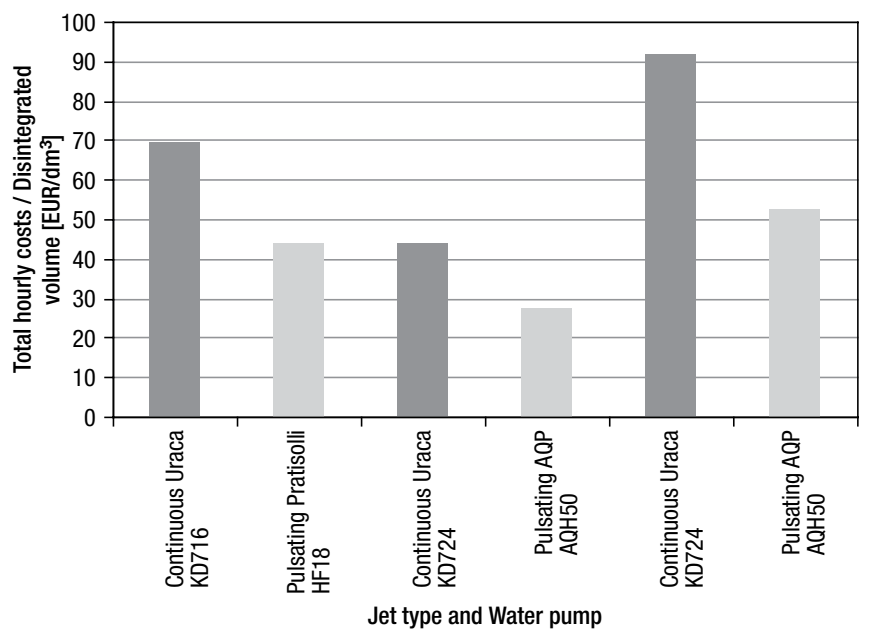

Fig. 4. Total hourly costs for continuous and pulsating water jets per $1 \mathrm{dm}^{3}$ disintegrated volume

\section{Results and discussion}

The results of the calculations clearly indicate that the use of advanced technology of pulsating water jet can reduce significantly the cost of the process of removing layers of damaged concrete in comparison with traditional methods of concrete removal by continuous high-speed water jets. While the same volume of concrete is removed, the total hourly costs are at least 1.6 times lower using pulsating jet. At higher pressures and water flows (resulting in higher amount of disintegrated concrete per unit time), the use of pulsating technology further reduces costs; the ratio reached 1.8 in our tests. Since both technologies are similar (based on the same principles), the use of pulsating jets yields greatest savings compared to the continuous ones in depreciation items covering total price of the equipment and related costs for repair, maintenance and spare parts. Also energy costs are lower when using pulsating jets.

\section{Conclusion}

Two research institutions - the Brno University of Technology, Faculty of Civil Engineering and the Institute of Geonics AS CR, v. v. i. and the industrial company Net Ltd. closely cooperated on solving tasks in the presented research of high speed water jets and the evaluation of effectiveness of this technology. The research tasks have been solved with the support of funding granted by Czech Science Foundation, by the Academy of Sciences of the Czech Republic and by Research and Development for Innovations Operational Program financed by Structural Funds of the European Union and from the means of state budget of the Czech Republic. This scheme of cooperation follows the Triple helix model. The success achieved by the research team (emphasized by the patents and positive evaluation of finished research projects) proves that Triple helix model cooperation is valuable. 
The paper is a contribution to cost evaluation and costs analysis of water jet technology. This paper aims to compare comprehensively in economic terms the costs of removing degraded layers of concrete using the technology of both continuous oscillating and pulsating oscillating water jets. The presented computation model is based on the model of Vidová (2007), completed by specific parameters used during evaluation of technology of high-speed water jet technology as formulated by Zeng and Kim (1993) and Singh and Munoz (1993). This new model comes from the assumption that total technological costs are the most important technical-economic indicator of the operation of machinery and equipment and also a suitable criterion for the comparison of variant solutions.

It should be pointed out that this particular example cannot be applied generally. It cannot be claimed that pulsating jet technology is more economical than other technologies considering wide diversity of applications where water jet is used. It is necessary to evaluate an actual case and then decide to apply one or the other technology. Regardless, it should be taken into account that pulsating jet technology is becoming a serious competitor to relatively widespread continuous jet technology in many areas.

\section{Acknowledgements}

The article was written in connection with the project of the Institute of clean technologies for mining and utilization of raw materials for energy use, reg. No. CZ.1.05/2.1.00/03.0082 supported by Research and Development for Innovations Operational Programme financed by Structural Funds of the European Union and from the means of state budget of the Czech Republic. The work was supported also by the Technology Agency of the Czech Republic, projects No. TA01010948 and Ministry of Industry and Trade of the Czech Republic, project No. FR-TI1/387.

\section{References}

Axinte, D. A.; Stepanian, J. P.; Kong, M. C.; McGoulay, J. 2009. Abrasive waterjet turning - an efficient method to profile and dress grinding wheels, Int. J. of Machine Tools \& Manufacture (49): 351-356. http://dx.doi.org/10.1016/j.ijmachtools.2008.11.006

Chlivickas, E.; Petrauskaite, N.; Ambrusevic, N. 2009. Leading priorities for development of the high technologies market, Journal of Business Economics and Management 10(4): 321-328. http://dx.doi.org/10.3846/1611-1699.2009.10.321-328

Etzkowitz, H.; Klofsten, M. 2005. The innovating region: toward a theory of knowledge-based regional development, $R \& D$ Management 35(3): 243-255.

http://dx.doi.org/10.1111/j.1467-9310.2005.00387.x

Hela, R.; Bodnárová, L.; Sitek, L.; Foldyna, J. 2010. High - speed water jet technology for renovation of concrete structures - new trends and possibilities, Cement-Wapno-Beton 5/2010: 268-278.

Krastel, K.; Drechsel, J. 1999. Integration of laser processing in machine tools and their economy, in Proc. of the Conference on Solid State Lasers VIII, San Jose, Jan 25-26, 1999. Ed. Scheps (SPIE 3613: 65-74).

Manetsch, T. J.; Huber, H. A. 1993. A comparative economic - analysis of automated and conventional hardwood lumber processing systems, Forest Products Journal 43(1): 35-40. 
McCurrich, L. H.; Browne, R. D. 1972. Application of water jet cutting technology to cement grouts and concrete, in 1st Int. Symp. Jet Cutting Technol. Eds. Brock, T. E.; Richardson, A. BHRA, Cranfield, G7/69-G7/91.

Medeot, R. 1989. History, theory, and practice of hydrodemolition, in $5^{\text {th }}$ American Water Jet Conference, Toronto, Canada. Aug. 1989, U.S: Water Jet Technology Association.

Momber, A. W. 2005. Hydrodemoliton of Concrete Surfaces and Reinforced Concrete Structures. Elsevier, Oxford.

Silfwerbrand, J. 1990. Improving concrete bond in repaired bridge decks, Concrete Int. 12(9): 61-66.

Singh, P. J.; Munoz, J. 1993. Cost optimization of abrasive water jet cutting systems, in 7th American Water Jet Conference. Seattle, Washington. WJTA, 191-204.

Sitek, L. 2009. Turning by high-speed abrasive water jet - our experiences, in Int. Conf. Vodni paprsek/Water Jet 2009: Proceedings. Ed. Sitek. Czech Republic. ÚGN, 160-169.

Sitek, L.; Foldyna, J.; Ščučka, J.; Młynarczuk, M.; Sobczyk, J. 2002. Quality of bottom surface of kerfs produced by modulated jets, in Proceedings of the 16th International Conference on Water Jetting, Aix-en-Provence, Lake (Ed.). BHR Group, 359-368.

Sitek, L.; Foldyna, J.; Wolf, I. 2009. Preparation of concrete substrates for repair by pulsating water jets, in Nowoczesne metody eksploatacji węgla $i$ skat zwięzlych. Ed. Filipowicz, F. AGH Krakow, 82-89.

Summers, D. A. 1995. Waterjetting Technology. E \& FN Spon, London.

Vidová, J. 2007. Model hodnotenia nákladov nekonvenčných technológií, Transfer Inovácii 10: 204-209.

Yan, W.; Tieu, A.; Ren, B.; Vijay, M. M.; Guruswami, G. 2004. Removal of delaminated concrete and cleaning the rust off the reinforcing bars using high-frequency forced pulsed waterjet, in Proceedings of 17th Int. Conf. Water Jetting - Advances and Future Needs. Mainz, Germany. BHR Group, Cranfield, 183-195.

Zeng, J.; Kim, T. J. 1993. Parameter prediction and cost analysis in abrasive water jet cutting operations, in 7th American Water Jet Conference. Seattle, Washington. WJTA, 175-189.

Rudolf HELA. Assoc. Prof. (*1959) graduated at the Brno University of Technology, Faculty of Civil Engineering in 1983. He finished his Ph.D. study at the field of Building technology in 1989. Since 2003 he is Assoc. Prof. at the Institute of Technology of Building Materials and Components in the Faculty of Civil Engineering at the Brno University of Technology (Czech Republic). He is a deputy head of the Institute. He specializes in the field of technology of manufacture of concrete and concrete parts and in the field of diagnostics of reinforced concrete structures. He is an expert in technology of concrete, designing of concrete mix-designs, development of special concrete with respect to frost resistance and resistance to corrosive environments, high-strength concrete and self-compacting concrete as well as technology of production of concrete construction elements - design of appropriate technologies including testing finished products.

Lenka BODNÁROVÁ. Ph.D. (*1971) graduated at the Brno University of Technology, Faculty of Civil Engineering in 1994. She finished her Ph.D. study at the field of Building Materials Engineering in 2000. From 1995 she works as a Research fellow/Instructor in the Institute of Technology of Building Materials and Components in the Faculty of Civil Engineering at the Brno University of Technology (Czech Republic). She is an expert in composite materials in Civil engineering and possibilities of use of technology of high speed water jet in civil engineering, in particular in the phase of preparation of surface for renovation of concrete structures. 
Miloslav NOVOTNÝ. Assoc. Prof. (*1955) graduated at the Brno University of Technology, Faculty of Civil Engineering in 1979. He finished his Ph.D. study at the field of Building Structures in 1984. Since 1999 he is Assoc. Prof. at the of Building Structures in the Faculty of Civil Engineering at the Brno University of Technology (Czech Republic). He is a head of the Institute and vicedean Faculty of Civil Engineering. He specializes in the field of Rehabilitation of Building Structures und Using of Microwawe Radiation.

Libor SITEK. Ph.D. (*1964) graduated at the Brno University of Technology, Faculty of Mechanical Engineering in 1988. He finished his Ph.D. study at the area of water jetting technology in 2000. From 1989 he works as a scientist at the Institute of Geonics ASCR, v. v. i. in Ostrava (Czech Republic). His research activities are primarily oriented at material disintegration by water jet technology as well as fundamental research on generation and behaviour of water jets.

Jiř́ KLICH. Mech. Eng. (*1984) graduated at the Technical University - VSB in Ostrava, Faculty of Mechanical Engineering in 2009. At present he is Ph.D. student at the area of water jetting technology. From 2009 he works as a scientist at the Institute of Geonics ASCR, v. v. i. in Ostrava (Czech Republic). His research activities are oriented at water jet technology and analysis of surface quality.

Ivan WOLF. Mech. Eng. $(* 1959)$ graduated at the Nitra Agriculture University, Faculty of Mechanical Engineering in 1983. In 1990 he founded private company NET, Ltd., o which provide high-pressure waterblasting and hydrodemolition work for industry. He closely cooperates with various academic institutes on research activities at the area of water jet.

Josef FOLDYNA. Ph.D. (*1958) graduated at the University of Mining and Metallurgy in Ostrava, Faculty of Mechanical Engineering in 1983. He finished his Ph.D. study at the area of water jet technology in 1997. From 1986 he works as a scientist at the Institute of Geonics ASCR, v. v. i. in Ostrava (Czech Republic), from 2006 as a head of Department of Material Disintegration. His research activities are oriented recently at the experimental research on generation of high-speed pulsating water jets, and determination of crucial parameters influencing the performance of pulsating jets. 